\title{
Underground Space Resource in Granitic Plutons and the Concept for an Underground Nuclear Power Plant with Collocated Facilities for Long-Term Storage and Deep Borehole Disposal of Spent Fuel
}

\author{
Geological Society of America \\ 2018 Southeastern Section Meeting \\ April $12-13,2018$, Knoxville, TN \\ C. W. Myers ${ }^{1}$, J.C. Reid ${ }^{2}$, R.H. Carpenter ${ }^{3}$
}

${ }^{1}$ Former Division Director, Earth and Environmental Sciences Division, Retired, Los Alamos National Laboratory, Los Alamos, N.M.; ${ }^{2}$ North Carolina Geological Survey - Raleigh, NC; ${ }^{3}$ North Carolina Geological Survey, Retired, Deceased. 


\section{Outline}

Objective

Prior Work

Granite Balds in Western North Carolina

Underground Space Advantages and Disadvantages

Granite Balds: Underground Space Benefits and Uses

Example: Underground Nuclear Power Plant with Collocated Deep Borehole Disposal

Summary and Recommendations 


\section{Underground Space-An Increasingly Important Geological Resource}

Long Term Objective: Evaluate the underground space resource in topographically elevated granite landforms and similar granitoid rock masses in the Southeastern U.S. (Blue Ridge and Piedmont).

Current Attention: Granite "balds" in western North Carolina.

Prior Work. Identified granite plutons in North Carolina and Virginia with potential for construction of refrigerated mined caverns for natural gas storage (Carpenter, Reid and Myers, 2017). 


\section{Prior Work*}

\section{Refrigerated Mined Cavern for Natural Gas Storage}
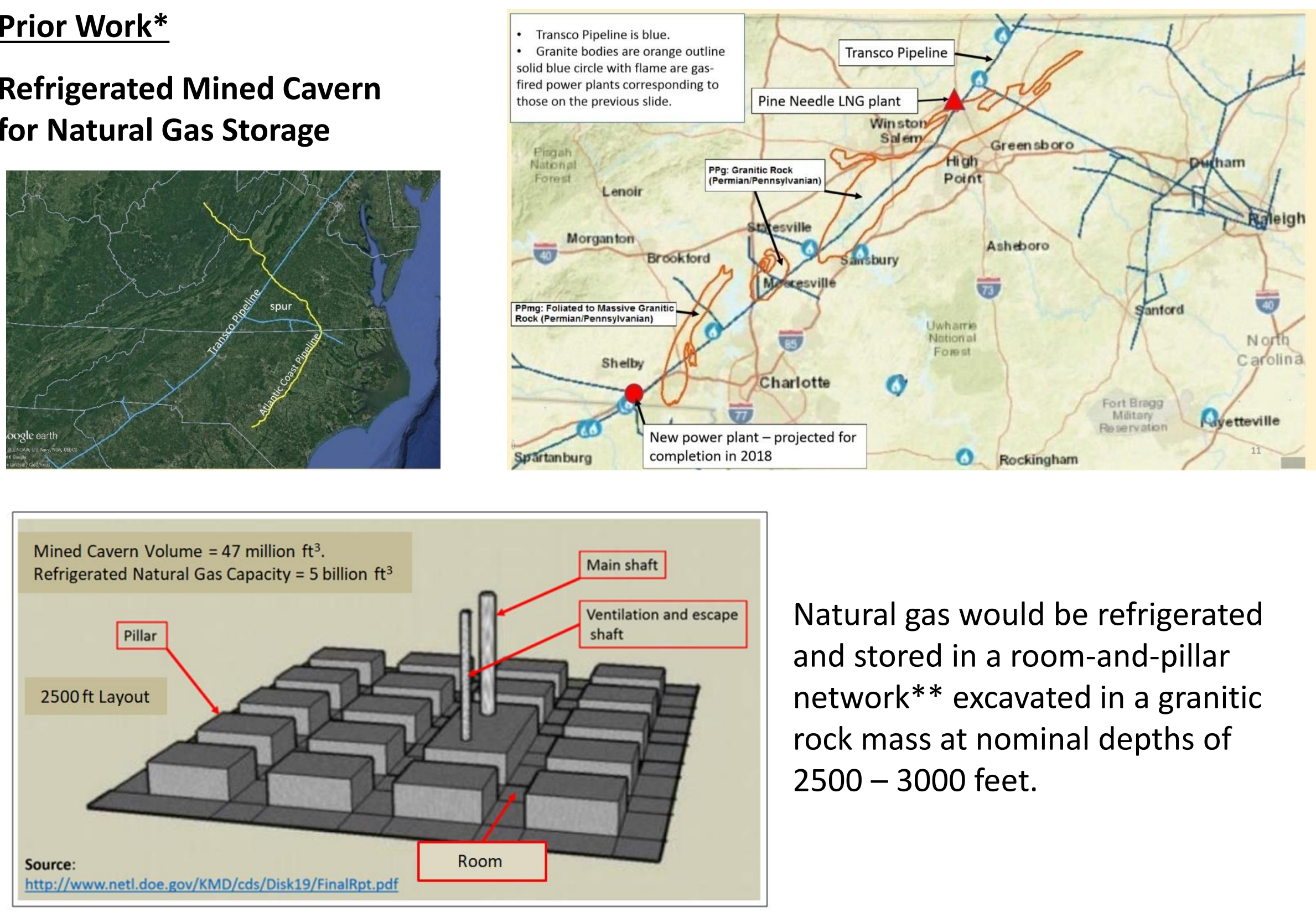

Natural gas would be refrigerated and stored in a room-and-pillar network** excavated in a granitic rock mass at nominal depths of $2500-3000$ feet.

*Carpenter, Reid, and Myers (2017)

** PB-KBB, (1998) 


\section{Current Attention: Granite Balds-Why?}

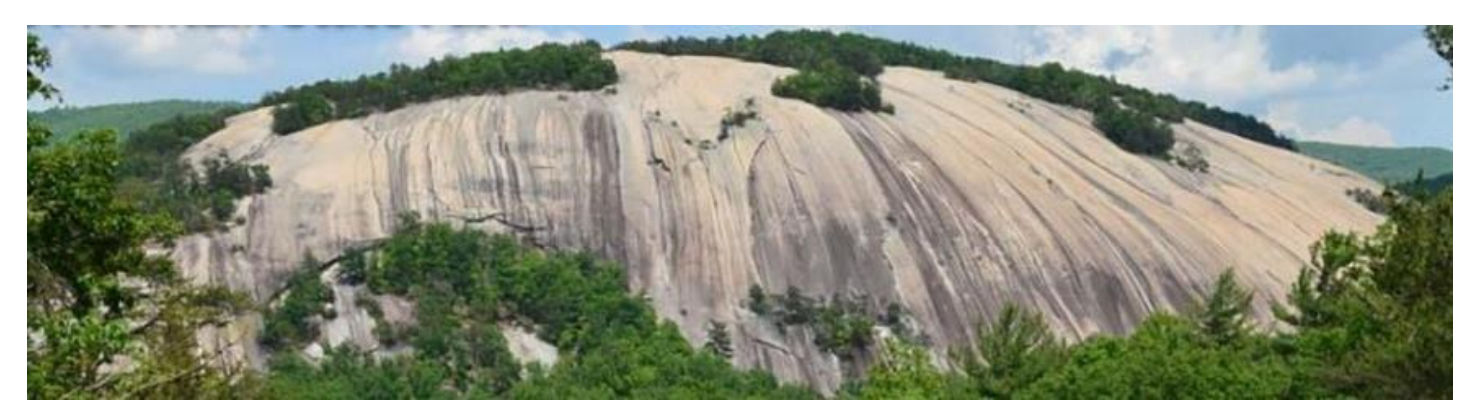

Plan View of a Hypothetical Granite Bald Outcrop

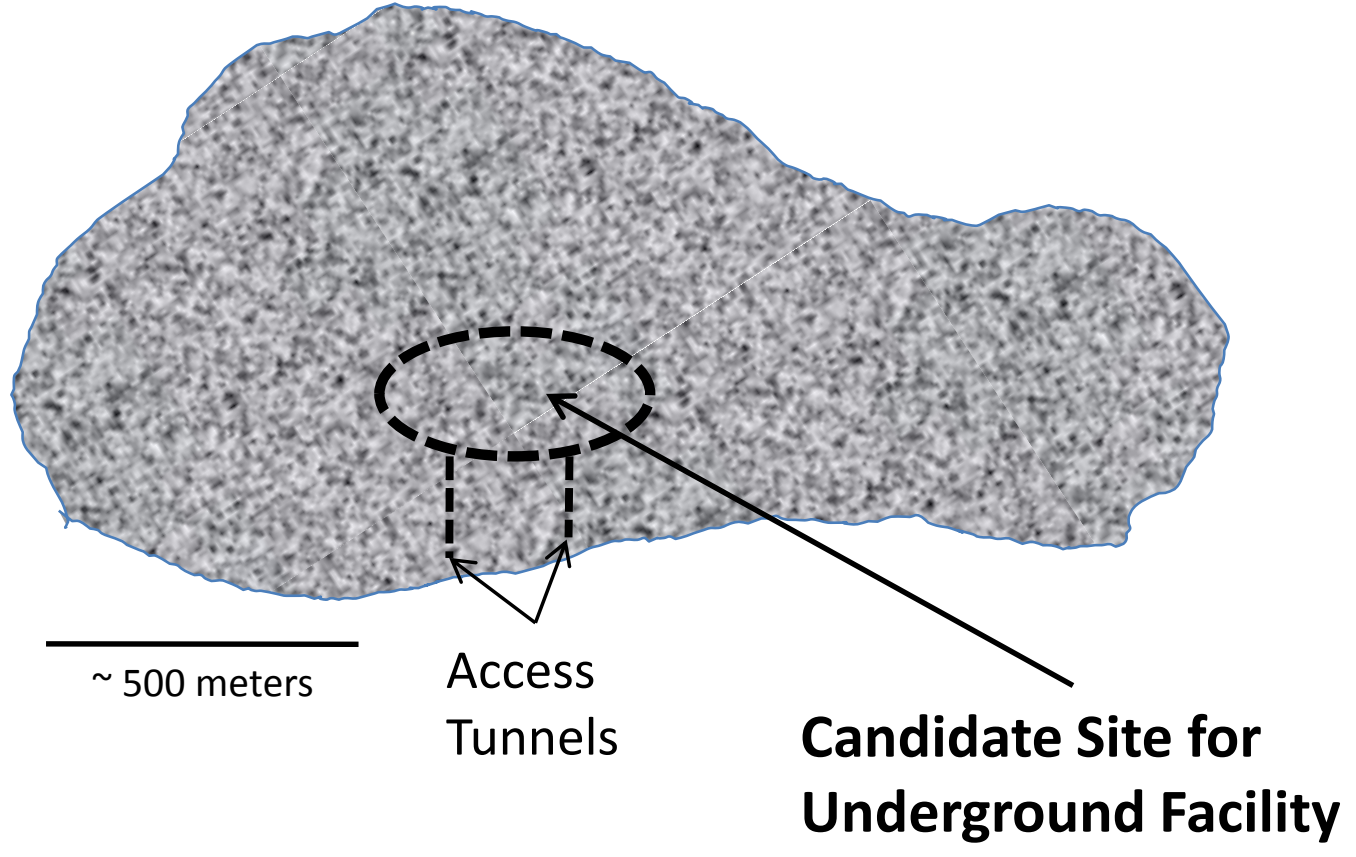

High probability of favorable geotechnical conditions in the interiors

- high mechanical strength

- low permeability

- suitable in situ stress conditions

- adequate size and dimensions for underground facility

Tunnel entry at ground level is possible.

- Low excavation cost relative to shaft entry,

- Direct vehicular access to the underground facility

The domal landform permits direct examination of the rock mass 


\section{Underground Space Advantages}

Enhanced Physical Protection

and Security

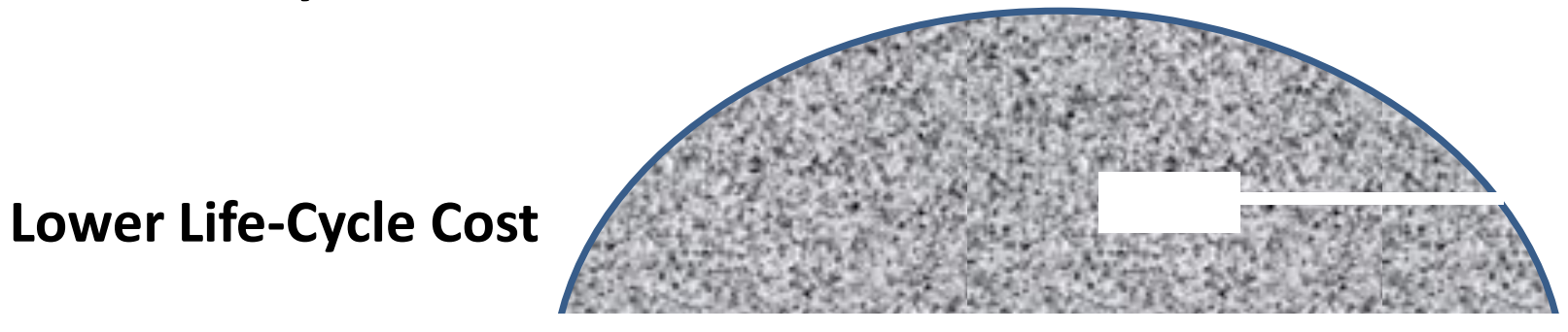

Preserved Landscape Aesthetics

Constant Temperature, Humidity, and Low Vibration

\section{Underground Space Disadvantages}

Higher Construction Cost (usually)
Safety and

Psychological Issues
Geology, Geography, and Land Use Limitations 


\section{Oblique View of Granite Balds in Western North Carolina:}

Looking Glass, John Rock, and Cedar Rock

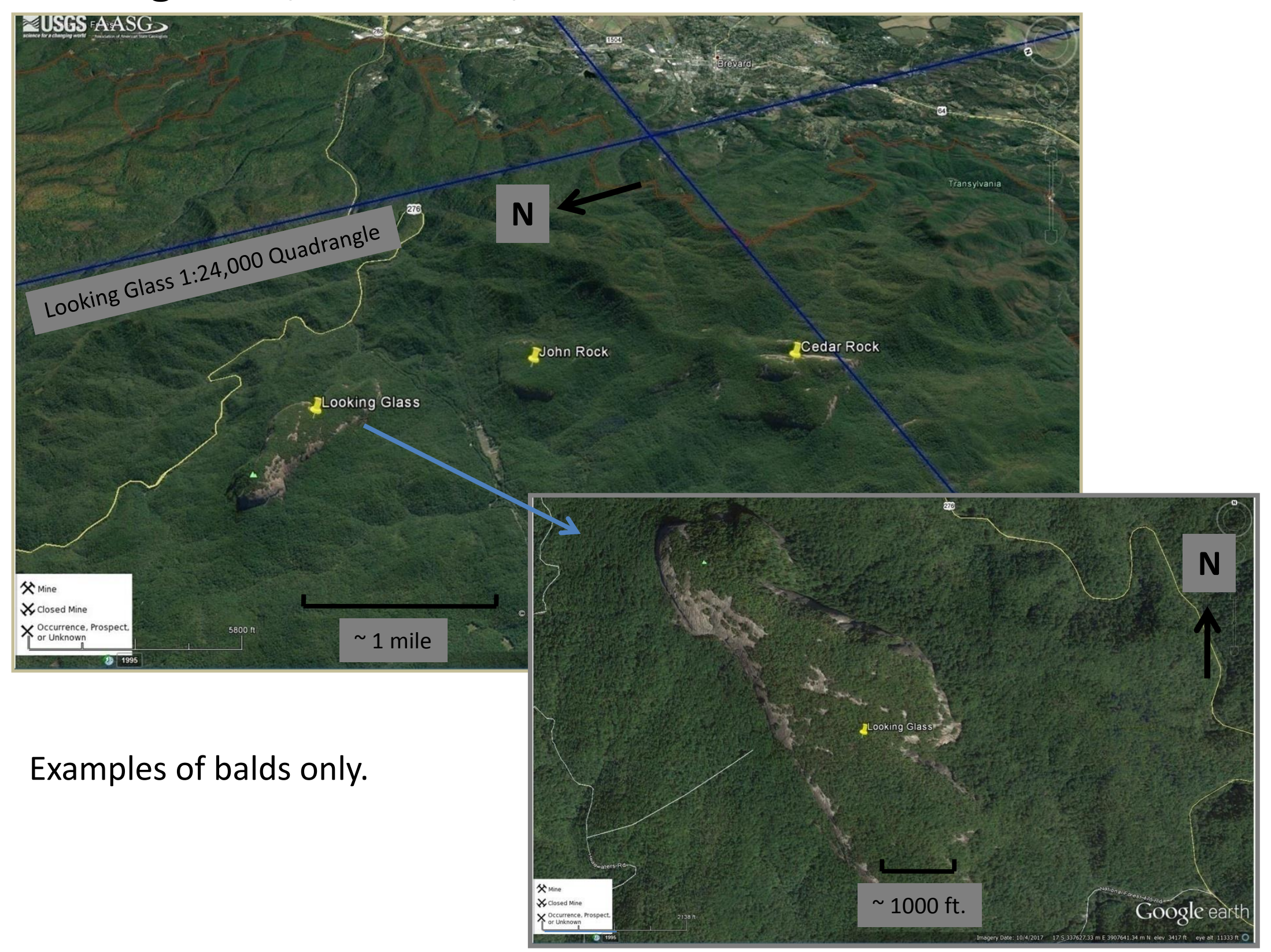




\section{Factors to Consider in Siting Underground Facilities in Granite Balds of Western North Carolina}

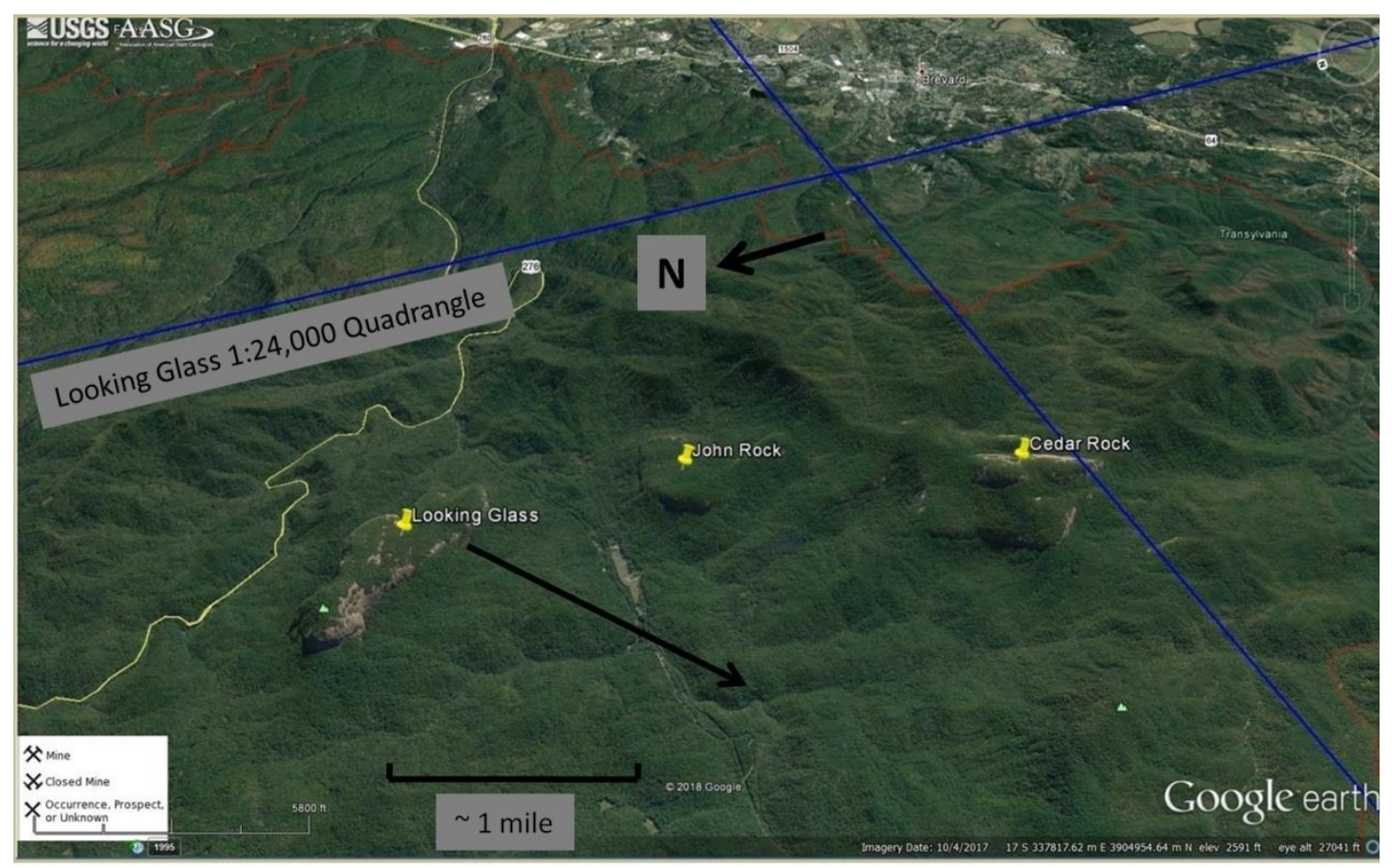

\section{Land Use}

- Ownership (Balds are mostly on U.S. Forest Service lands)

- Benefits/Impacts:

- Land and Water Use

-Environment and Ecosystems

-Visual Aesthetics

- Proximity to Nearby Populations

\section{Economics and Engineering}

- Regional and Local Benefits Economic Diversification Rural Development

- Proximity to Regional Electrical Grid

- Transportation Infrastructure

- Water Availability 


\section{Potential Uses}

-Regional Military, FEMA or DHS

-- Command Centers

-- Emergency Equipment/Supply Depots

-Refrigerated/Frozen Food EXAMPLE Storage

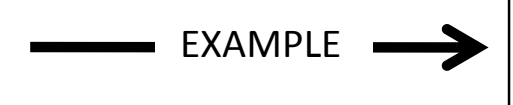

-Specialized Manufacturing EXAMPLE Plants

- Critical infrastructure facilities

-- Data storage

-- Communications

-- Energy storage and supply

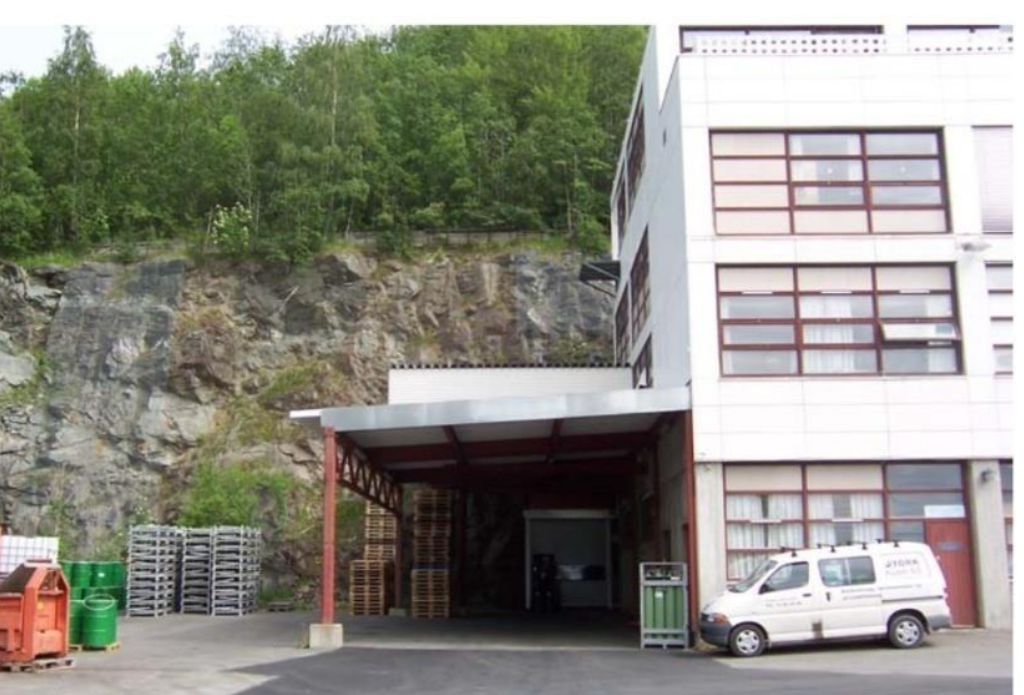

Staur frozen food storage cavern, Norway

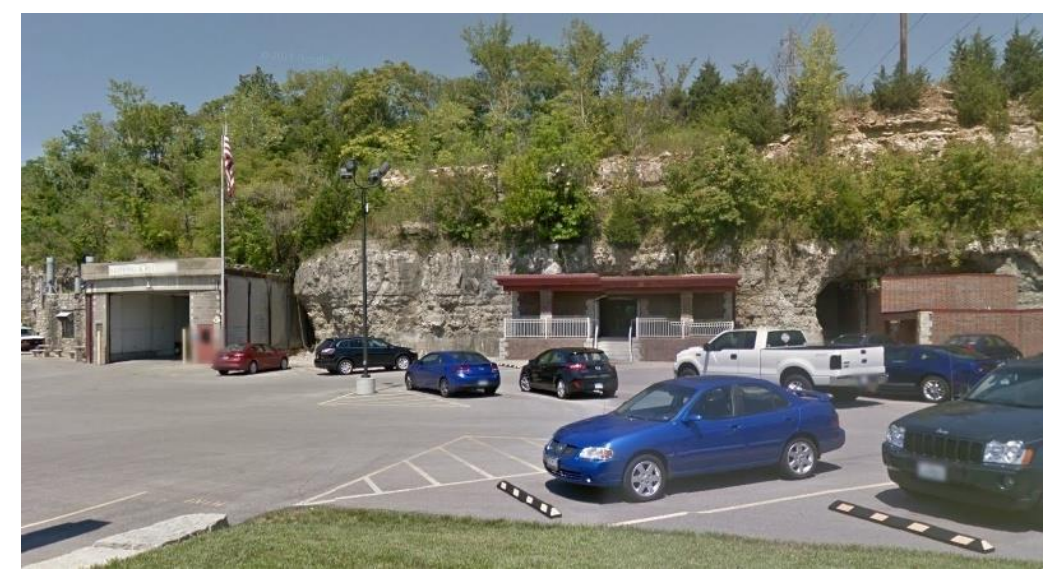

Brunson Instrument Company, Kansas City 


\section{Seismic Risk}

Subway Tunnel Experience

\begin{tabular}{|l|c|c|l|}
\hline Earthquake & Date & Magnitude & Impact on Subway \\
\hline Mexico City & 1985 & 8,1 & $\begin{array}{l}\text { No damage to tunnels. } \\
\text { Some power disruption. } \\
\text { Patrons evacuated safely }\end{array}$ \\
\hline Loma Prieta (SF) & 1989 & 6,9 & $\begin{array}{l}\text { No damage to tunnels. Subway ser- } \\
\text { ved as lifeline structure. }\end{array}$ \\
\hline Northridge & 1994 & 6,7 & No damage \\
\hline Kobe, Japan & 1995 & 7,2 & $\begin{array}{l}\text { No damage to tunnels, damage to } \\
\text { station and sewer pipes. Attributed } \\
\text { to 1962 design with moderate seismic } \\
\text { provision }\end{array}$ \\
\hline Taipei & 2002 & 6,8 & No damage \\
\hline Chile & 2010 & 8,8 & $\begin{array}{l}\text { Running next day. Some damage at } \\
\text { entrance to station }\end{array}$ \\
\hline
\end{tabular}

Underground Hydropower Stations (Japan)

1) Numappara power station ( $200 \mathrm{~m}$ deep --Magnitude 5.5 at distance of $124 \mathrm{~km}$

--30.3gal at surface

--14.5gal underground

2) Shiyroyama power station ( $200 \mathrm{~m}$ depth) --ratio of maximum accelerations, underground/surface

-- $1 / 3$ to $1 / 2$ horizontal

$--1 / 2$ to 1 vertical

---Earthquake motion tends to be attenuated with increasing stiffness ( competence) of the bedrock.

---Earthquake motion is, in general, lower at depth than at the surface. A "...factor of two...is a reasonable, conservative first estimate at all depths". (Douglas, 2006)

---Engineered supports between internal components and the and the cavern walls, floor and roof will reduce inertial response.

---Site-specific studies might be needed for granite balds, including consideration of topographic effects. 


\section{Energy Supply Example: Underground Nuclear Power Plant (UNPP)}

Granite plutons might become a preferred option for siting critical infrastructure facilities---such as a nuclear power plant-because of the inherent benefits.

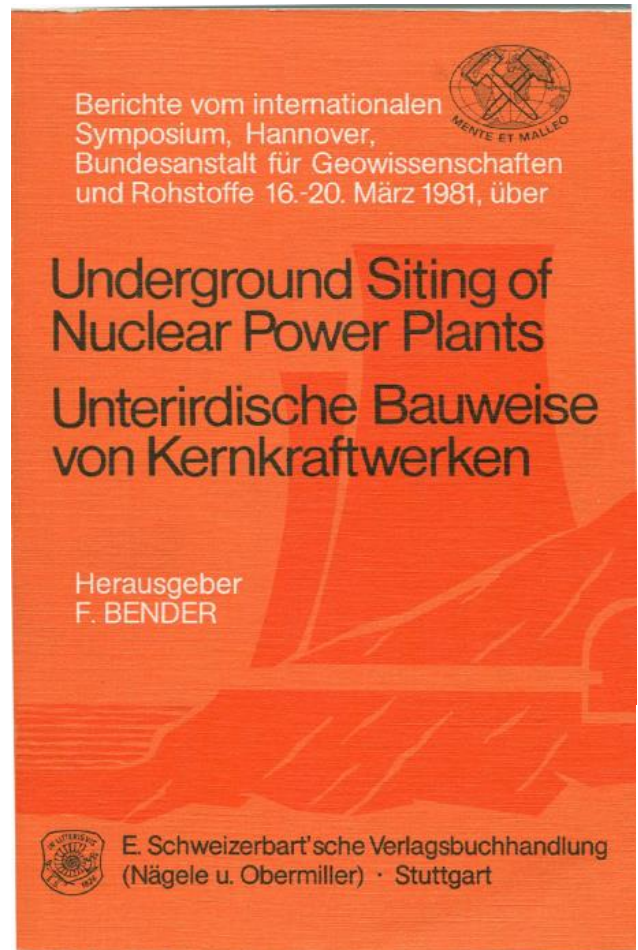

$\mathrm{NOK} / \mathrm{m}=$ Norwegian Kroner/meter

\section{Background}

UNPPs were studied extensively in 1970s. Several probable advantages relative to surface-sited nuclear power plants: physical security against attack...superior containment....improved earthquake protection ...tornado/hurricane protection...natural radiation shielding...etc

Underground construction cost was the issue. However, that was in the 1970s. Since then, technological advances have lowered the cost of underground excavation.

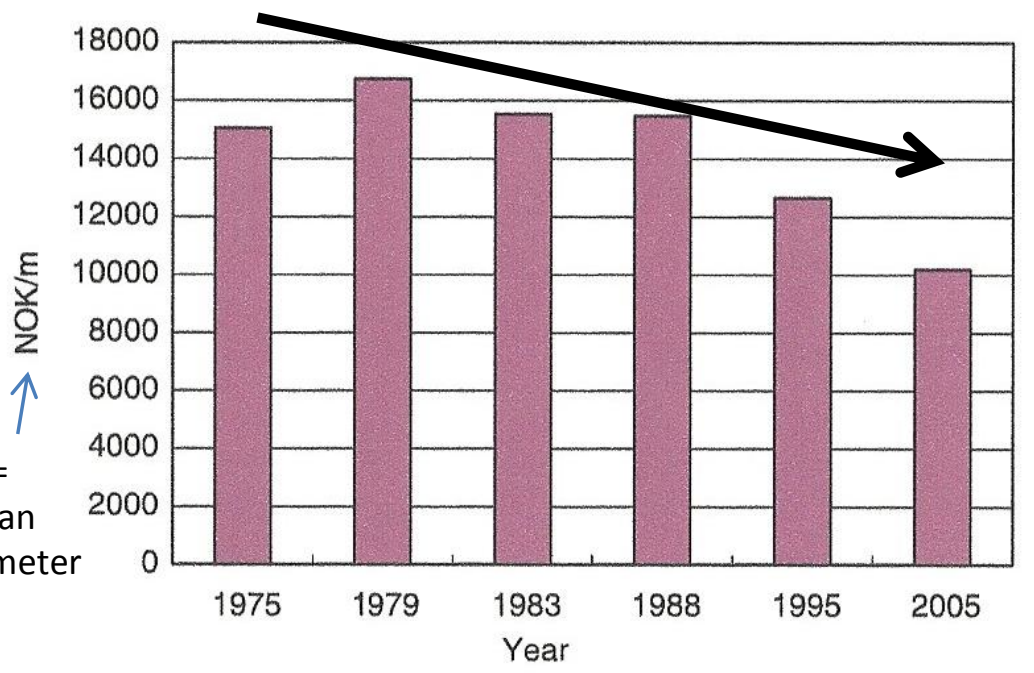

...a $35 \%$ cost reduction from 1975 to 2005 in drill-and-blast excavation for $60 \mathrm{~m}^{2}$ tunnels in Norway. (Zare and Bruland, 2007) 


\section{NuScale Small Modular Reactor}

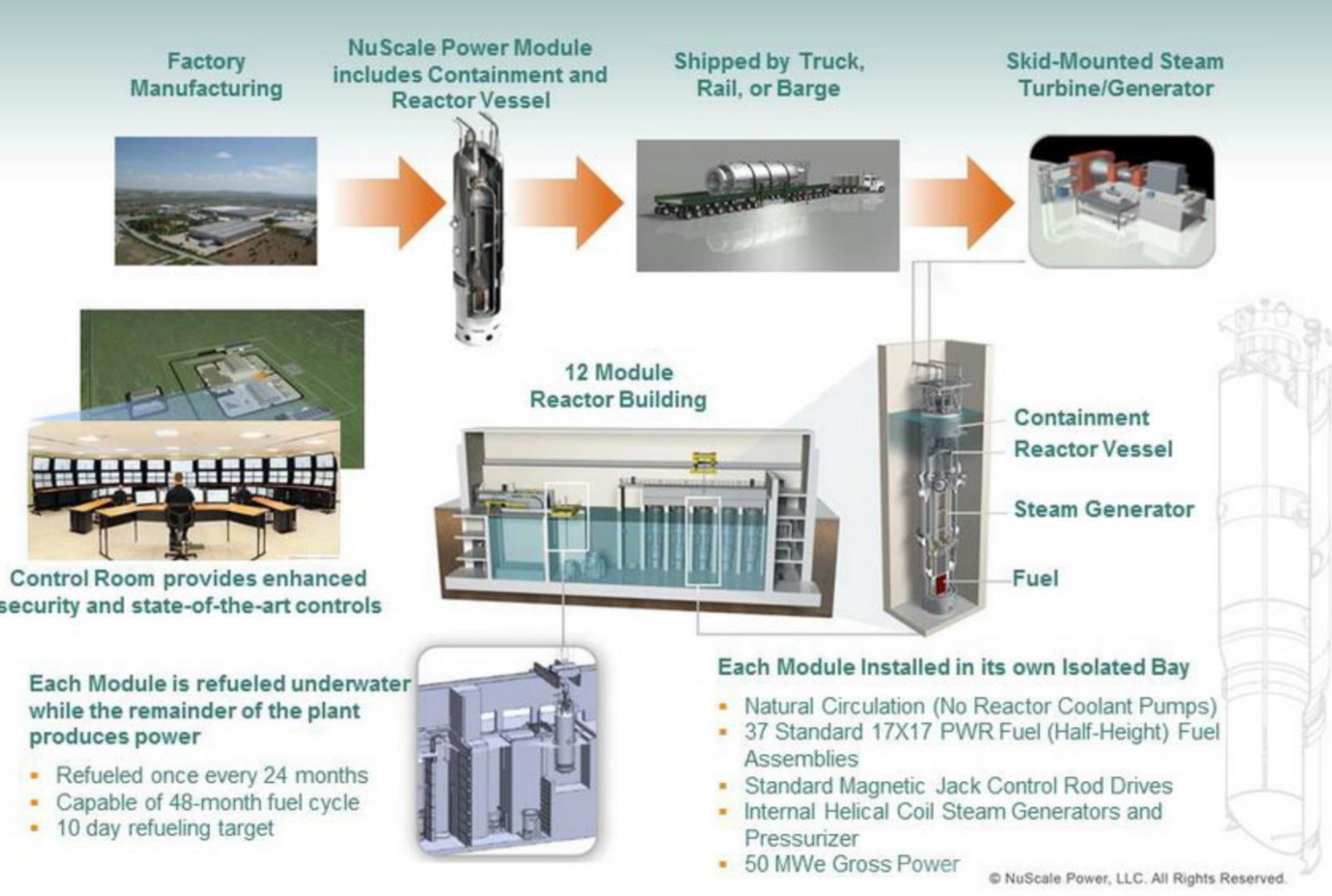




\section{Layout for the 1200MWe UNPP}
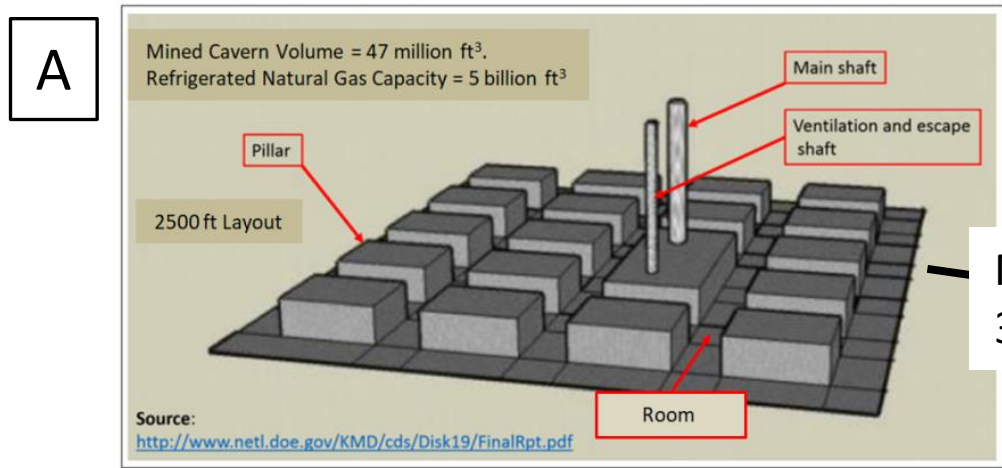

\section{Modified the}

$3000 \mathrm{ft}$ layout

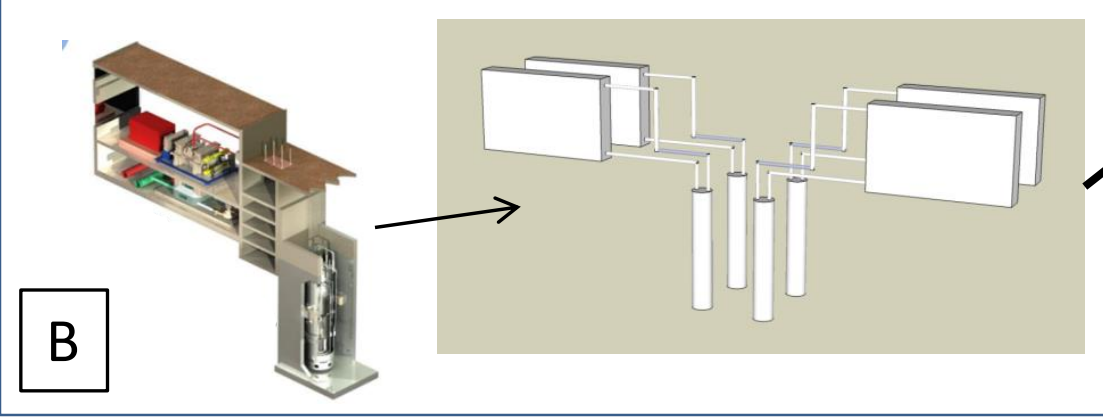

A. PB-KBB Room-and-Pillar Network

B. NuScale Reactor + Turbine/Generator/Condenser Pair

C. Layout in Room and Pillar network

D. Close-up pillars nearest viewer removed

E. Reactor Pool

F. Reactor Pool Channel

G. Spent Fuel Pool 


\section{Interesting Option: UNPP + Collocated Deep Borehole Disposal Facility}

At-reactor, deep borehole disposal of spent fuel produced by the UNPP reactors at a nominal depth of 4000 meters in a granite/high grade metamorphic rock mass

Long - term isolation of radionuclides would be promoted by

- Low Permeability Rock Mass

- Groundwater

--High-Salinity,

--Geochemically Reducing Chemistry, --Long Residence Time

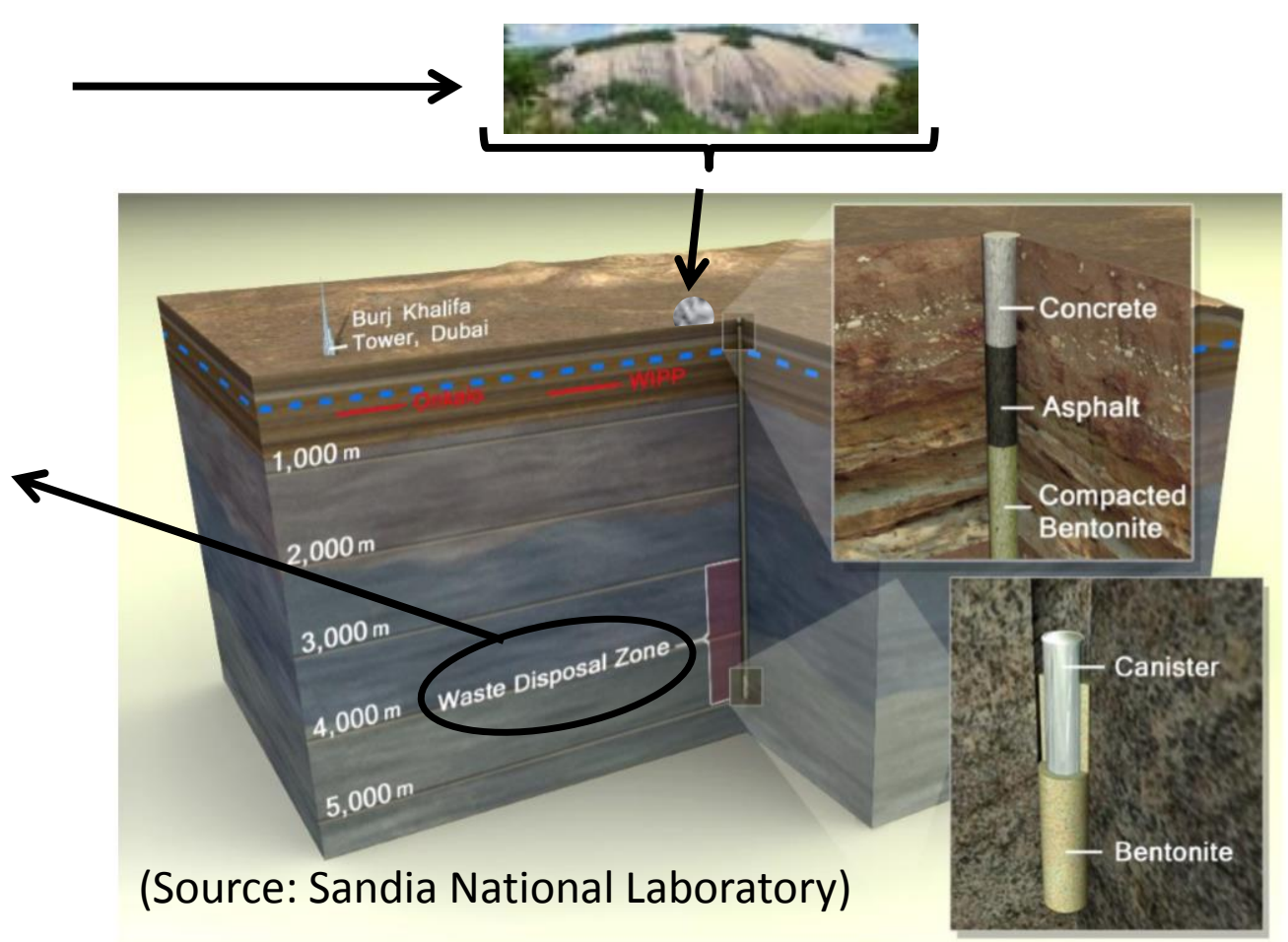

Advantages:

- Eliminates the health, safety, and cost issues associated with long-distant transport of spent fuel

- Promotes environmental justice,

Estimated spent-fuel disposal cost for the $1200 M W e$ UNPP is $\sim \mathbf{\$ 2 4 0}$ million. 
More work is required to determine the total estimated UNPP construction cost. For example, the cost to finish the underground facility must be determined (i.e., install ventilation, cooling, utilities, concrete, bulkhead/seals in rooms, etc).

Nonetheless, the estimated excavation cost of $\mathbf{2 8 0 M}$ for the 1200MWe UNPP would be $<5 \%$ of the estimated $\$ 5,790 \mathrm{M}$ overnight cost for two NuScale $600 \mathrm{MWe}$ plants (based on Colbert, 2013). Therefore, the historical perception that UNPPs in bedrock caverns will be too expensive might no longer be valid.

We do not recommend that granite balds in western north Carolina be evaluated for UNPPs at this time. However, we do recommend that the option be evaluated if small modular reactors are considered for deployment in the Blue Ridge and Piedmont regions of the southeastern U.S.

In the near term, UNPP siting could be of interest to SMR vendors considering SMR nuclear power plant deployments in granitic terrains elsewhere in the world...

...especially in global regions having high risk of terrorist or enemy nation attack and/or extreme risk from natural phenomena. 


\section{Summary and Recommendations}

Use of underground space is increasing globally - a more proactive approach should be taken to evaluate underground space resources in the U.S.

Exploration geology techniques should be used to discover and evaluate rock masses with potential for siting underground facilities.

For example, granite plutons and similar rock masses having favorable geotechnical and geohydrological properties should be evaluated for siting....

- commercial and manufacturing facilities

- regional centers for emergency response, civil and military defense, and storage of strategically important supplies

- critical infrastructure facilities for communications, document and data storage, and energy storage and supply.

Specifically, granite balds, such as those in western North Carolina, could be promising rock masses for underground space development...

- their interiors probably contain large masses of granite with high strength and low permeability

- ground-level tunnel entry is possible 


\section{Sources and Additional Information}

Slide 4.

Carpenter, Robert H.; Reid, Jeffrey C., and Myers, C.W., 2017, Underground Storage of Refrigerated Natural Gas in Granite of the Southeastern U.S." North Carolina Geological Survey, Open-file Report 2017-02, 29 document pages.

Design of the room-and-pillar network is from PB-KBB, 1998, "Advanced Underground Gas

Storage Concepts Refrigerated-Mined Cavern Storage," Final Report, DOE Contract Number DE-AC26-97FT34349, 162 pages. Available at https://www.osti.gov/scitech/biblio/7510

\section{Slide 9.}

The Staur deep freeze storage cavern is described in Broch, E. 2007, "Use of the Underground in the City of Trondheim," 11th ACUUS Conference: "Underground Space: Expanding the Frontiers", September 10-13 2007, Athens - Greece. Available at https://www.researchgate.net/publication/266220908 Use of the Underground in the City of Trondheim Norway.

The Bunsen Instrument Company uses underground space to provide a vibration-free, temperature-stable facility for the precise machining and adjustment processes needed to manufacture high-precision instruments. Information is available at http://www.brunson.us/metrology-optical-measurement-products-alignment-about-brunson/metrology-optical-measurementproducts-alignment-brunson-history/

\section{Slide 10}

The chart on subway tunnels is from "Report on Underground Solutions for Urban Problems," 2012, International Tunneling and Underground Space Association, ITA Report N011, April 2012. Available at https://about.ita-aites.org/publications/wgpublications/224-underground-solutions-for-urban-problems.

Douglas, J. 2006, "Estimating Strong Motions at Great Depths," 2006, Third International Symposium on the Effects of Surface Geology on Seismic Motion, Grenoble, France, 30 August - 1 September, 2006, Paper Number 30.

Information on the Numappara and Shiyroyama underground hydropower plants is from the paper by Hiroya Komada, Masao Hayashi, Yoshitada Ichikawa and Yoshiaki Ariga, 1982, "Characteristics of Earthquake Motions Around Underground Powerhouse Caverns," in H. F. Bender, (Ed.) 1982, Proceedings of a Symposium on Underground Siting of Nuclear Power Plants, E. Schweizerbart'scheVerlagsbuchhandlung, Stuttgart, Germany, 412 p. 


\section{Sources and Additional Information (continued)}

\section{Slide 11.}

The 1970s studies of underground nuclear power plants are summarized in H. F. Bender, (Ed.) 1982, Proceedings of a Symposium on Underground Siting of Nuclear Power Plants, E. Schweizerbart'scheVerlagsbuchhandlung, Stuttgart, Germany, $412 \mathrm{p}$.

Zare, S. and A. Bruland, 2007, "Progress of drill and blast tunneling efficiency with relation to excavation time and cost," in Underground Space - the $4^{\text {th }}$ Dimension of Metropolises - Bartak, Hrdina, Romancov \& Ziamal (eds), 2007, Taylor \& Francis Group, London, ISBN 978-0415-40807-3, pages $805-808$. Available at

https://www.researchgate.net/publication/288704161 Progress of drill and blast tunnelling efficiency with relation to excavation ti $\underline{\text { me and costs }}$

Slide 12.

Information on the NuScale small modular reactor is available at http://www.nuscalepower.com/

Slide 14.

The extensive analyses of deep borehole disposal of nuclear waste performed at Sandia National Laboratory are described in Patrick V. Brady, Geoffrey A. Freeze, Kristopher L. Kuhlman, Ernest L. Hardin, David C. Sassani, and Robert J. MacKinnon, "Deep Borehole Disposal of Nuclear Waste", Chapter X in Geological Repository Systems for Safe Disposal of Spent Nuclear Fuels and Radioactive Waste, 2nd Edition Ed. Joonhang Ahn and Michael Apted. Available at https://arxiv.org/abs/1707.05736. Additional information is given in the references in that article. 


\section{Thank You for Your Attention}

\section{Contacts:}

Wes Myers, myerswes@msn.com

Jeff Reid, jeff.reid@ncdenr.gov 